Check for updates

Cite this: RSC Adv., 2017, 7, 33219

\title{
Multifunctional cellulose-containing fabrics using modified finishing formulations
}

\author{
Nabil A. Ibrahim, ${ }^{\text {B }}$ Basma M. Eid, ${ }^{a}$ Eman Abd El-Aziz, ${ }^{\text {b }}$ Tarek M. Abou Elmaaty (D) *c \\ and Shaimaa M. Ramadan ${ }^{\mathrm{C}}$
}

Several metal oxide nanoparticles (MO-NPs), namely $\mathrm{ZrO}-\mathrm{NPs}, \mathrm{ZnO}-\mathrm{NPs}$, and $\mathrm{TiO}_{2}-\mathrm{NPs}$, have been used to modify traditional finishing formulations to develop multifunctional cotton-containing fabrics. The fabrics used were cotton (100\%), cotton/polyester blend (65/35) and cotton/polyester blend (50/50), which were treated with each finishing formulation using the pad-dry-cure technique. The imparted functional properties in the absence and presence of the nominated MO-NPs were evaluated. The positive effects of the incorporated MO-NPs in improving and/or imparting new functional properties, like easy-care, UV-protection, antibacterial functionality, water and oil repellency and flame proofing efficiency, were shown to be governed by the type of substrate and its cellulosic/polyester components, type of MO-NPs, finishing formulation components and mode of interaction between the active ingredients and active sites of the treated substrate. Tentative mechanisms were suggested, and the surface modification and composition of the selected fabric samples were analyzed using SEM and EDX. Future studies will further investigate the impact of incorporating the nominated MO-NPs with other active ingredients in the finishing formulation on the durability of fabric against washing, as well as on the change in other performance and physicomechanical properties.

\author{
Received 12th May 2017 \\ Accepted 16th June 2017 \\ DOI: 10.1039/c7ra05403c \\ rsc.li/rsc-advances
}

\section{Introduction}

Using cotton, a natural cellulosic fiber, alone and in combination with other natural or synthetic fibers is highly desirable for many reasons, such as achieving the properties of biodegradability, hydrophilicity, breathability, comfortability and versatility. ${ }^{1-3}$ On the other hand, the demand for multifunctional cotton-containing textiles has remarkably increased to overcome the inherent drawbacks, and to meet the ever-growing demands of textile end-users, such as antibacterial activity, UV-protection functionality, softness, easy-care, flame retardancy, and water and oil repellency, ${ }^{4-11}$ as well as to develop innovative textile products that are of high quality, possess desirable functionality and have increased added value..$^{3,4,12,13}$

Accordingly, the main task of the present work was to search for appropriate finishing formulations, using certain organic/ nanometal oxide hybrid materials, to impart multifunctional and durable properties to various cotton-containing substrates, namely cotton $(100 \%)$, cotton/polyester (65/35) and cotton/

${ }^{a}$ Textile Research Division, National Research Centre, Scopus Afflitiation ID 60014618, (El-Behouth St.),Dokki, Giza, Egypt.E-mail: nabibrahim49@yahoo.co.uk; basmaeid@ yahoo.com; Fax: +20233370931

${ }^{b}$ Faculty of Applied Arts, Printing, Dyeing and Finishing Department, Benha University, Benha,Egypt.E-mail: emanabdelaziz@hotmail.com

${ }^{c}$ Department of Textile Printing, Dyeing and Finishing, Faculty of Applied Arts, Damietta University, Damietta, Egypt.E-mail: tasaid@du.edu.eg; designer_shemo@ yahoo.com polyester (50/50) fabrics, taking into account both applicability and environmental concerns, as well as consumer demands.

\section{Experimental}

\subsection{Materials}

Mill-scoured and bleached plain weave cotton (160 $\left.\mathrm{g} \mathrm{m}^{-2}\right)$, cotton/polyester $\left(65 / 35,140 \mathrm{~g} \mathrm{~m}^{-2}\right)$ and cotton/polyester $(50 / 50$, $250 \mathrm{~g} \mathrm{~m}^{-2}$ ) fabrics were used. Arkofix® NEC EG liq. (low formaldehyde crosslinking agent, based on modified $\mathrm{N}$-methylolodihydoxyethylene urea, DMDHEU, Clariant, Switzerland), Ultratex® FMW silicone softener (micro-emulsion based on amino-modified polydimethylsiloxane, Huntsman, USA), UVSUN® CEL liq. (reactive UV-absorber based on oxanilide, Huntsman, USA), Flovan ${ }^{\circledR}$ CWF (non-durable flame retardant based on an aqueous solution of nitrogen-phosphate and sulfate compounds, Huntsman, USA), Oleophobol® CO (oil/ water and stain repellent finish based on a dispersion of fluoropolymers containing extender, Huntsman, USA), and HEIQ ${ }^{\circledR}$ pure TF (antimicrobial freshness cationic agent based on a silver compound, Huntsman, USA) were of commercial grade. Nanometal oxides, namely ZnO-NPs (10-30 nm), $\mathrm{TiO}_{2}-\mathrm{NPs}$ (10-30 nm) and ZrO-NPs $(0.3-0.5 \mathrm{~nm})$, in powder form were obtained from SkySpring nanomaterials, Inc., USA. All other chemicals used in this study, such as citric acid (CA), magnesium chloride hexahydrate $\left(\mathrm{MgCl}_{2} \cdot 6 \mathrm{H}_{2} \mathrm{O}\right)$, Polyethylene glycol 
(PEG-300) and nonionic wetting agent, were of laboratory reagent grade.

\subsection{Methods}

2.2.1. Nanometal oxide aqueous dispersion. Aqueous dispersions of $\mathrm{ZnO}-\mathrm{NPs}, \mathrm{TiO}_{2}-\mathrm{NPs}$ and $\mathrm{ZrO}-\mathrm{NPs}$ were prepared by adding PEG ( $\left.2 \mathrm{~g} \mathrm{~L}^{-1}\right)$, under continuous stirring, into the presonicated nanometal oxide dispersion in deionized water according to the reported method. ${ }^{\mathbf{1 4}}$

2.2.2. Functional coating of cotton-containing fabrics. The fabric samples were padded twice to achieve a wet-pickup of $80 \%$ with an aqueous finishing formulation containing DMDHEU (50 $\mathrm{g} \mathrm{L}^{-1}$ ) as a crosslinking agent, and $\mathrm{MgCl}_{2}$ $\cdot 6 \mathrm{H}_{2} \mathrm{O} / \mathrm{CA}\left(10 / 2 \mathrm{~g} \mathrm{~L}^{-1}\right)$ as a mixed catalyst, along with one of the nominated finishing agents, namely a silicone softener (30 $\left.\mathrm{g} \mathrm{L}^{-1}\right)$, UV-absorber $\left(30 \mathrm{~g} \mathrm{~L}^{-1}\right)$, flame retardant $\left(200 \mathrm{~g} \mathrm{~L}^{-1}\right)$, water/oil repellent $\left(50 \mathrm{~g} \mathrm{~L}^{-1}\right)$ and an antibacterial agent $(30 \mathrm{~g}$ $\mathrm{L}^{-1}$ ), in the absence and presence of the nominated nanometal oxides $\left(25 \mathrm{~g} \mathrm{~L}^{-1}\right)$. The samples were then dried at $100{ }^{\circ} \mathrm{C}$ for $3 \mathrm{~min}$, cured at $150{ }^{\circ} \mathrm{C} / 3 \mathrm{~min}$ and washed to remove unfixed and excess reactants at $50{ }^{\circ} \mathrm{C}$ for $15 \mathrm{~min}$, in the presence of $2 \mathrm{~g} \mathrm{~L}^{-1}$ nonionic wetting agent. Finally, the samples were thoroughly rinsed, dried again and conditioned for evaluation.

\subsection{Characterization}

Scanning electron microscope (SEM) images of the selected fabric samples were obtained on a JEOL, JXL 840A electron probe microanalyser, equipped with energy dispersive X-ray (EDX) spectroscopy for surface elemental composition analysis.

\subsection{Tests}

The nitrogen contact (N\%) of the finished fabric samples was evaluated according to the Kjeldhal method. ${ }^{15}$ The dry wrinkle recovery angle (WRA) was determined according to the AATCC Test Method 66-1995. ${ }^{16}$ The roughness of the untreated and softener-loaded fabric samples was assessed using a SE $1700 \alpha$, Japan, in accordance with JIS B0601-'94 standard. ${ }^{17}$ The antibacterial capability of the untreated and functionalized fabric samples was qualitatively evaluated against Gram positive (G+ve, $S$. aureus) and Gram negative (G-ve, E. coli) bacteria according to the AATCC Test Method (147-1988), and expressed as the zone of growth inhibition $(\mathrm{mm}) .^{18}$

UV-protection functionality, expressed as UV-protection factor (UPF), was assessed according to the AS/NZS 4399:1996, and protection was rated as good, very good or excellent, when UPF values were $15-24,25-39$, or above 40 , respectively. ${ }^{19}$ The water repellency (WRR) rating and oil repellency rating (ORR), were evaluated using the Spray Test Method 22-2005 ${ }^{20}$ and AATCC Test Method 118-2013, respectively. ${ }^{21}$ The flame retardation properties of the untreated and treated fabric samples were analyzed using the flame test procedure US CPSC 16 CFR PART $1610 .^{22}$

\section{Results and discussion}

The present study focused on investigating the positive role of including $\mathrm{ZrO}-\mathrm{NPs}, \mathrm{ZnO}-\mathrm{NPs}$ or $\mathrm{TiO}_{2}-\mathrm{NPs}$ into certain conventional finishing formulations, using the pad-dry-cure technique, to develop high performance multifunctional cotton-containing textiles for diverse potential applications, such as apparel fabrics and household textiles, etc.

\subsection{Characterization of the treated cotton fabrics}

The SEM images and EDX spectra of the untreated cotton and cotton treated with silicone softener, in the absence and presence of ZnO-NPs, are presented in Fig. 1. The surface morphology of the untreated cotton sample shows a clean surface (Fig. 1a), while the surface of the softener-treated fabric sample shows the distribution of a thin film on the fabric surface (Fig. 1c). A good deposition of Zn-NPs particles was also observed on the softener-finished fabric surface in the presence of ZnO-NPs (Fig. 1e). The EDX spectra of the treated fabric samples confirm the existence of $\mathrm{Si}$ and the presence of Si and $\mathrm{Zn}$, for the samples prepared in the absence and presence of the ZnO-NPs, respectively, along with the existence of $\mathrm{N}$ in both spectra due to the finishing and softening agents used, compared with the EDX spectrum of the untreated sample.

Fig. 2 shows the surface morphology change and the analysis of the EDX spectrum of the treated cotton fabrics with the organic UV-absorber, UV-Sun ${ }^{\circledR}$, in the presence of the ZnO-NPs. The SEM image in Fig. 2c shows a heavy deposition of particles related to both UV-Sun ${ }^{\circledR}$ and $\mathrm{ZnO}-\mathrm{NPs}$, and some agglomeration of these particles at the upper layer of the finished fabric surface can be obviously seen. The existence of $\mathrm{Zn}$ along with other elements, i.e., $\mathrm{C}, \mathrm{O}$ and $\mathrm{N}$, is presented in the EDX spectrum of the finished fabric sample.

On the other hand, SEM images and EDX spectra of the cotton fabric samples finished using Oleophobol® CO, without and with $\mathrm{TiO}_{2}-\mathrm{NPs}$, are shown in Fig. 3. A thin layer of the water/ oil repellent agent is distributed along the fiber surface, as shown in Fig. 3a. In Fig. 3c, the deposition of MO-NPs particles can be observed clearly on the fabric surface. On the other hand, the EDX spectrum of the fabric finished with Oleophobol ${ }^{\circledR} \mathrm{CO}$ in the absence of $\mathrm{TiO}_{2}-\mathrm{NPs}$ shows a fluorine peak (Fig. 3b), while the spectrum of the finished fabric in the presence of $\mathrm{TiO}_{2}-\mathrm{NPs}$ shows a Ti peak related to the $\mathrm{TiO}_{2}-\mathrm{NPs}$ used in the finishing formulation, along with other elements, i.e., $\mathrm{F}, \mathrm{N}, \mathrm{C}$ and $\mathrm{O}$.

Additionally, the differences in the deposition of HEIQ ${ }^{\circledR}$ Pure TF used as an antibacterial agent on the surface of the finished fabric sample in the absence and presence of Zn-NPs can be clearly noticed in the SEM images in Fig. 4a and c. The EDX spectra confirm the existence of $\mathrm{Ag}$ related to the antibacterial agent used alone (Fig. 4b), and also confirm the existence of $\mathrm{Ag}$ and $\mathrm{Zn}$ in the case of using the antibacterial agent in the presence of $\mathrm{Zn}-\mathrm{NPs}$.

Finally, Fig. 5 illustrates the SEM images and EDX spectra of the cotton fabric samples treated with Flovan ${ }^{\circledR}$ CWF in the absence and presence of Zn-NPs. Fig. 3a shows the deposition 

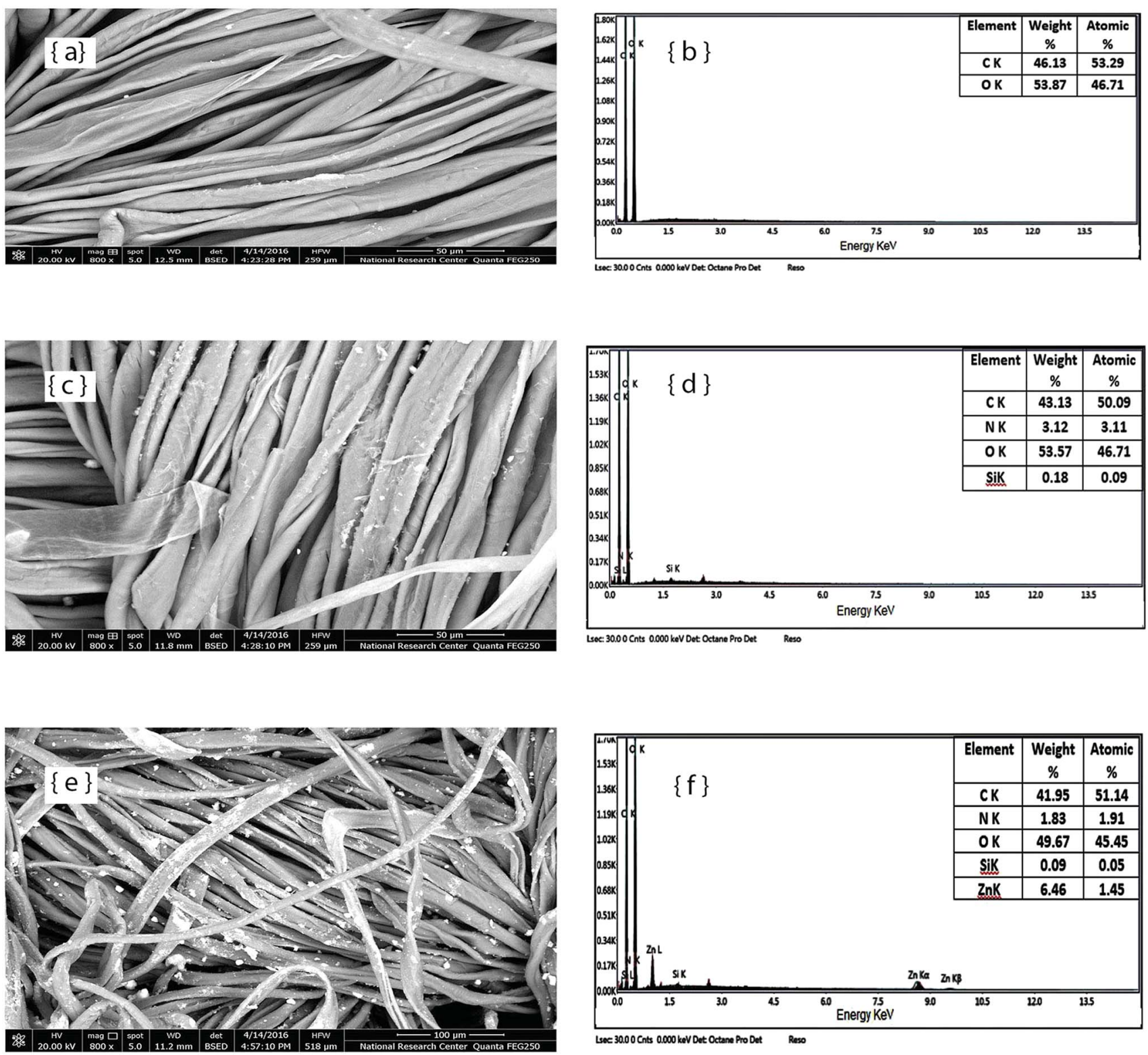

Fig. 1 SEM images and EDX spectra of untreated cotton fabric (a and b); fabric finished with silicon softener (c and d); fabric finished with silicon softener in the presence of $\mathrm{ZnO}-\mathrm{NPs}(\mathrm{e}$ and $\mathrm{f}$ ).

of the Flovan ${ }^{\circledR}$ CWF particles on the finished fabric surface, and this deposition can be also seen in Fig. 3c, along with the deposition of different types of particles that are attributed to the existence of $\mathrm{Zn}$-NPs on the fabric surface. The EDX spectra of the fabric treated with the flame retardant agent show peaks of phosphorous and sulfur and an increase in the percentage of nitrogen compared with the other finishing formulations. These elements are attributed to the flame retardant used as a finishing agent and are present in the spectral patterns of the finished fabric samples without and with MO-NPs in the finishing formulation, while an additional $\mathrm{Zn}$ peak can be clearly observed in the EDX spectrum of the fabric treated with Flovan ${ }^{\circledR} \mathrm{CWF}$ in the presence of $\mathrm{Zn}$ NPs (Fig. 5d).

\subsection{Easy-care finish}

For a given set of easy-care finishing conditions, the data in Table 1 signify that: (i) combined easy-care and softener treatment of the nominated substrates results in a significant increase in the \% $\mathrm{N}$ and fabric resiliency (expressed as WRA), as a direct consequence of the ether-crosslinking of cellulose chains and the formation of an elastic network due to the amino functional groups in the silicone softener; ${ }^{23-29}$ (ii) the use of easy-care/softener-finishing treatments is accompanied by a decrease in surface roughness, along with a slight improvement in UV-blocking and antibacterial functionality against the nominated pathogens, i.e. G+ve (S. aureus) and G-ve (E. coli) bacteria, compared with the untreated ones; (iii) the enhancements in the softness and protection properties are attributed 

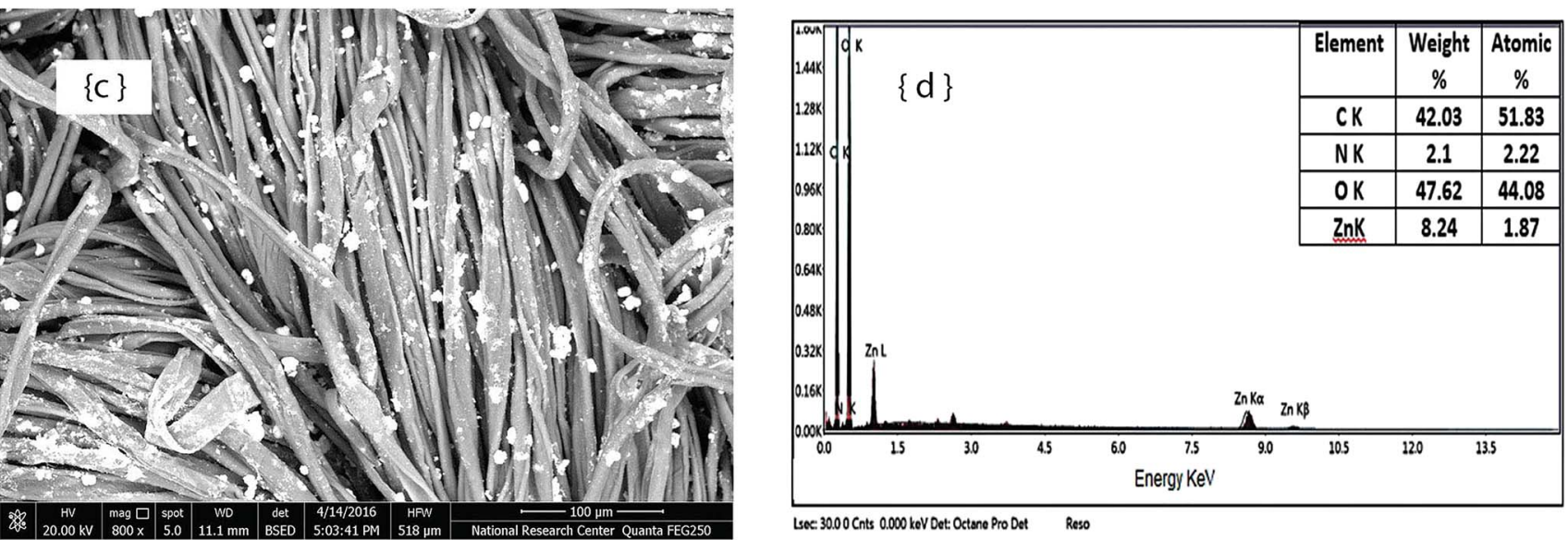

Lsec: 30.00 Cnts 0.000 koV Oet: Octene Pro Det Reso

Fig. 2 SEM images and EDX spectra of cotton fabric finished with UV-finishing agent (UV-Sun®) in the presence of ZnO-NPs.
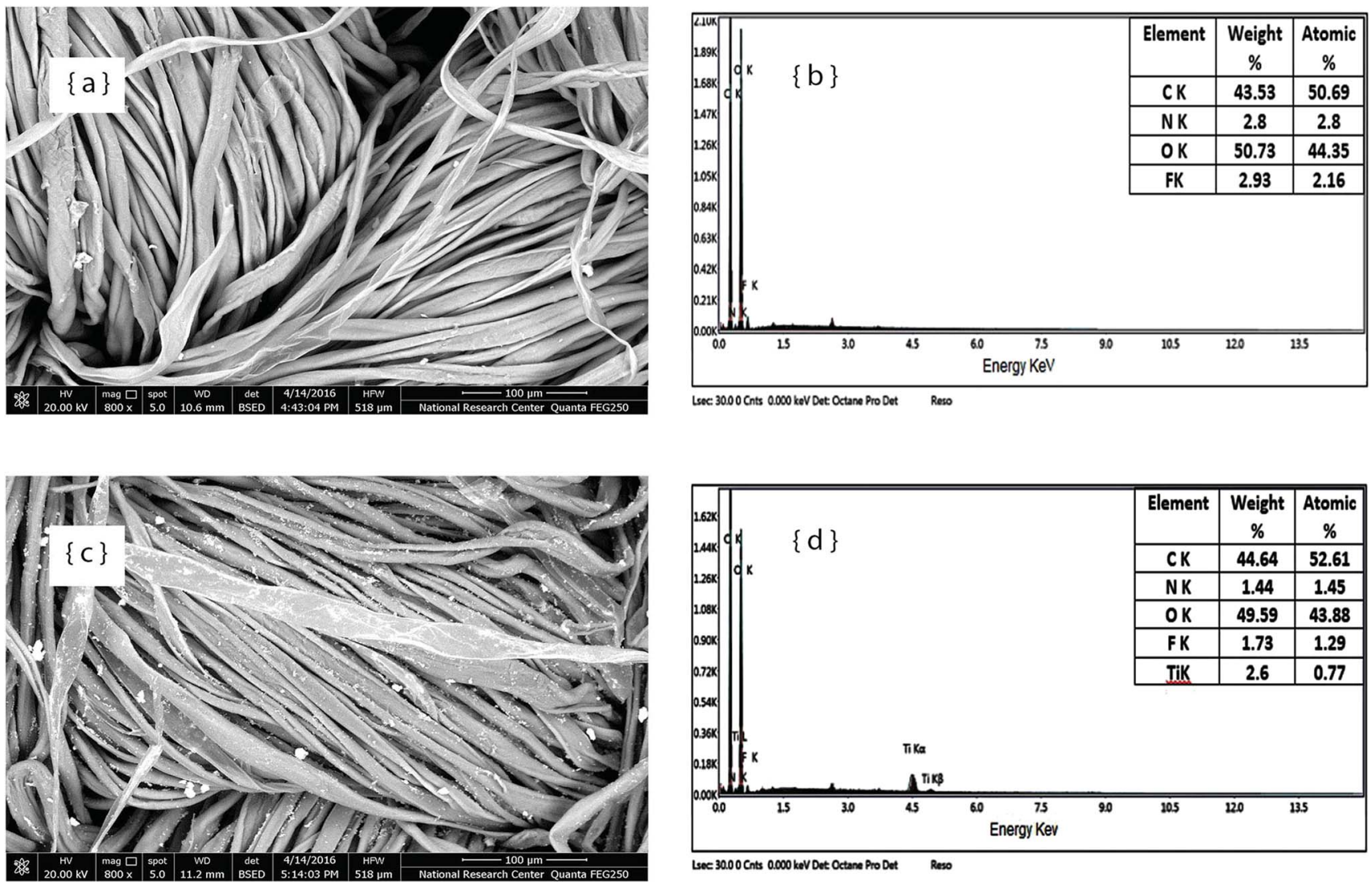

Fig. 3 SEM images and EDX spectra of cotton fabric finished with water/oil agent Oleophobol $® \mathrm{CO}(\mathrm{a}$ and $\mathrm{b})$; and finished with water/oil agent in the presence of $\mathrm{TiO}_{2}-\mathrm{NPs}$ ( $\mathrm{c}$ and d).

to the positive effect of the silicone softener on the surface coating, as well as the changes in the surface morphology and properties due to the positive active sites in acidic medium, i.e. $-\mathrm{N}^{+} \mathrm{H}_{3}$, along with the antibacterial effect of the used reactant resin; ${ }^{30,31}$ (iv) the variation in the obtained fabric properties is determined by the type of substrate, e.g. fabric weight, cellulose/ polyester component, amorphous/crystalline ratio, surface morphology, location, distribution and extent of loading of the active ingredients, as well as the extent of modification of the treated substrates; ${ }^{13,23,24}$ (v) among the finished substrates, cotton/polyester (50/50) blend fabric offers the highest fabric resiliency and softness, along with best UV- and antibacterialprotection properties.

It is also clear from Table 1 that the individual inclusion of the nominated nanomaterials into the finishing formulation is accompanied by a marginal increase in $\% \mathrm{~N}$, an improvement in 

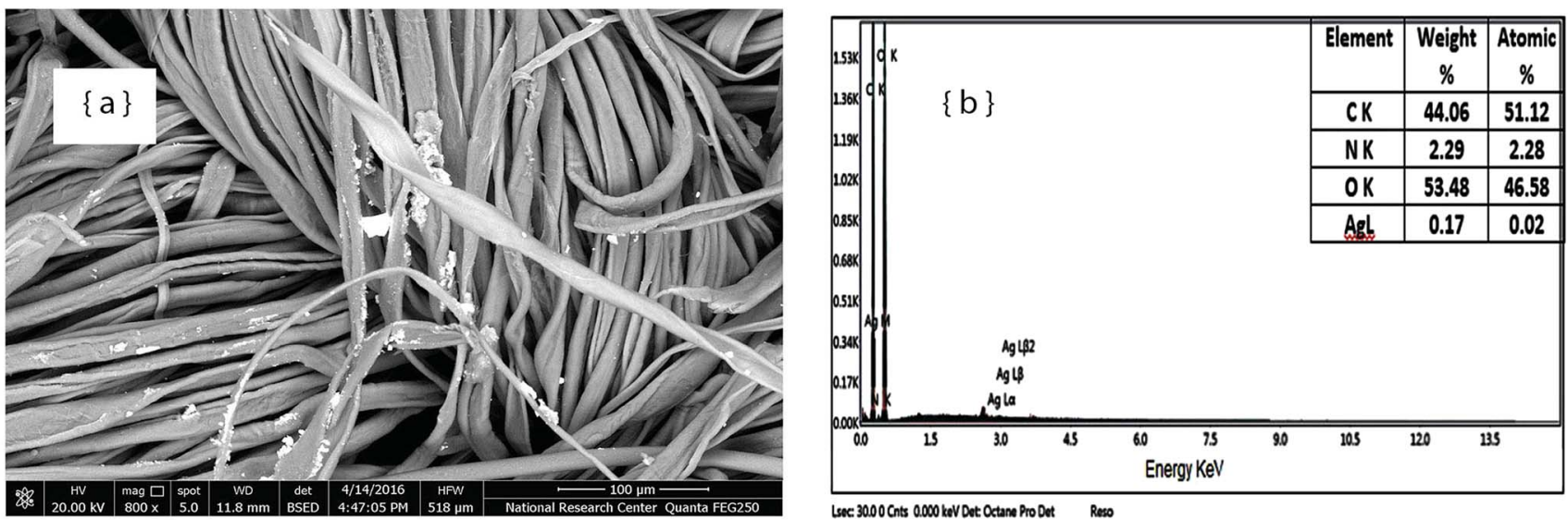

Lsec 30.00 Cints 0.000 keV Dot Otane Pro Dot Reso
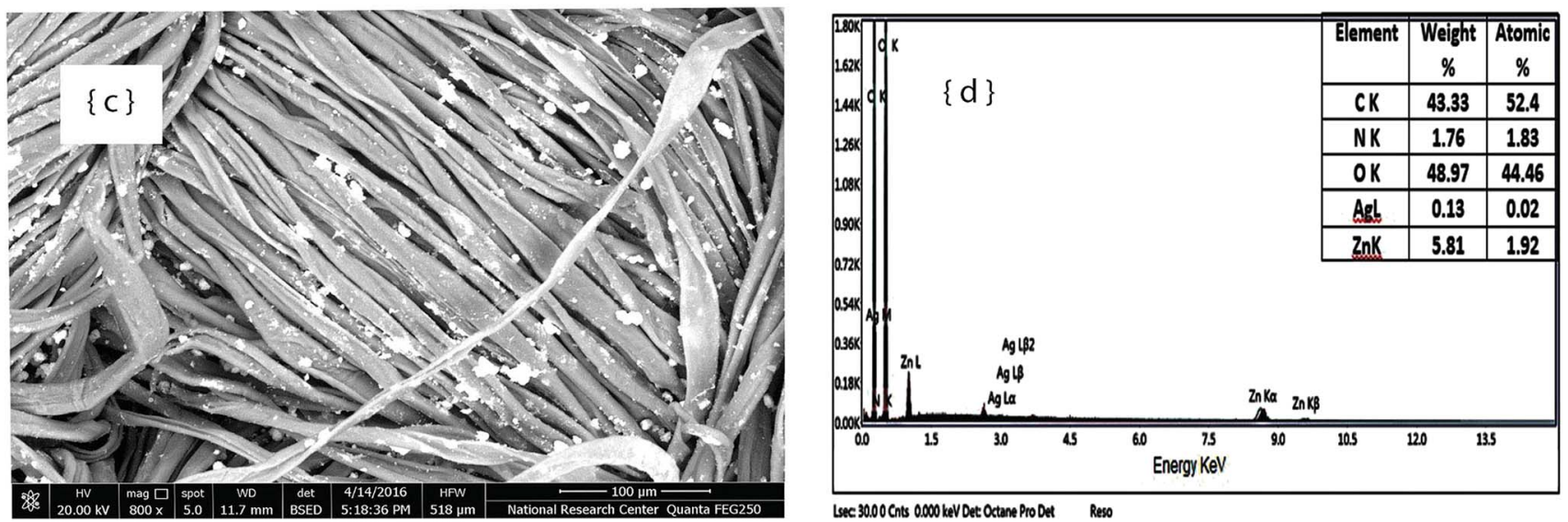

Lec 30.00 Cnts 0.000 keV Det Octane Pro Det Reso

Fig. 4 SEM images and EDX spectra of the cotton fabric finished with the antibacterial agent HEIQ® Pure TF (a and b); and finished with the antibacterial agent in the presence of $\mathrm{ZnO}-\mathrm{NPs}$ (c and d).

fabric resiliency, a slight variation in surface rigidity and a remarkable improvement in both the anti-UV and antibacterial functionalities, regardless of the substrate used. The marginal increase in \% $\mathrm{N}$ and the reasonable improvement in the WRA values highlight the positive role of the added nanomaterials in accelerating and enhancing the extent of catalyzation and fixation of the crosslinker and the silicone softener onto/within the fabric structure. ${ }^{3,25}$ Moreover, the slight increase in surface rigidity is a direct consequence of the surface immobilization of the used nanometal oxides onto the fabric surface, taking both the particle size and amount into consideration.

Additionally, the remarkable improvement in the UVprotection capability of the nanometal oxide-loaded substrates can be discussed in terms of their ability to block and shield from harmful UV-rays, especially UV-B $(\lambda: 280-315 \mathrm{~nm})$. The extent of the improvement in the UV-protection capability is governed by the type of substrate, fabric morphology, polyester content, extent of crosslinking/coating and loading of the nominated nanometal oxides, as well as the ability of the nanoparticles to be loaded onto the fabric surface, to improve the UV-absorption capacity of the textile materials. ${ }^{12,32,33} \mathrm{Among}$ the nanometal oxide-loaded substrates, the $\mathrm{TiO}_{2}-\mathrm{NP}$-loaded ones demonstrated the highest UPF value to protect human skin.

Moreover, the obvious increase in the antibacterial efficacy of the nanometal oxide-loaded substrates indicate their photocatalytic activity and ability to generate many reactive oxygen species (ROS), including hydroxyl radicals, superoxide anions and singlet oxygen, during photo-oxidation, which in turn can attack and destroy the pathogenic bacteria cells..$^{26,27}$ The ZnO-NP-loaded substrates show the best antibacterial functionality, expressed as the ZI value, among the loaded nanometal oxides (Table 1).

The imparted antibacterial functionality against the nominated pathogens follows the decreasing order: $\mathrm{G}+\mathrm{ve}>\mathrm{G}-\mathrm{ve}$, probably due to the differences in their cell wall structure. ${ }^{28}$ The variation among the nanometal oxides in the imparted antibacterial functionality can be discussed in terms of differences between their photocatalytic activities, extent and location of loading, and compatibility with other ingredients, which in turn affect their ability to confer antibacterial functionality.

Based on the above mentioned results and discussion, the following simplified tentative mechanism demonstrates the interactions among the cellulose containing substrate ( $\mathrm{S}-\mathrm{Cell}{ }^{\circ} \mathrm{OH}$ ), the finishing agent $\left(\mathrm{ROH}_{2} \mathrm{CN} \sim\right.$ F.Agent $\left.\sim \mathrm{NCH}_{2} \mathrm{OR}\right)$, the amino functional silicone softener (AFSir $\sim \mathrm{NH} \sim \mathrm{NH}_{2}$ ) and the nanometal oxide particles (MO-NPs). $)^{2,3,12,24,34}$ 

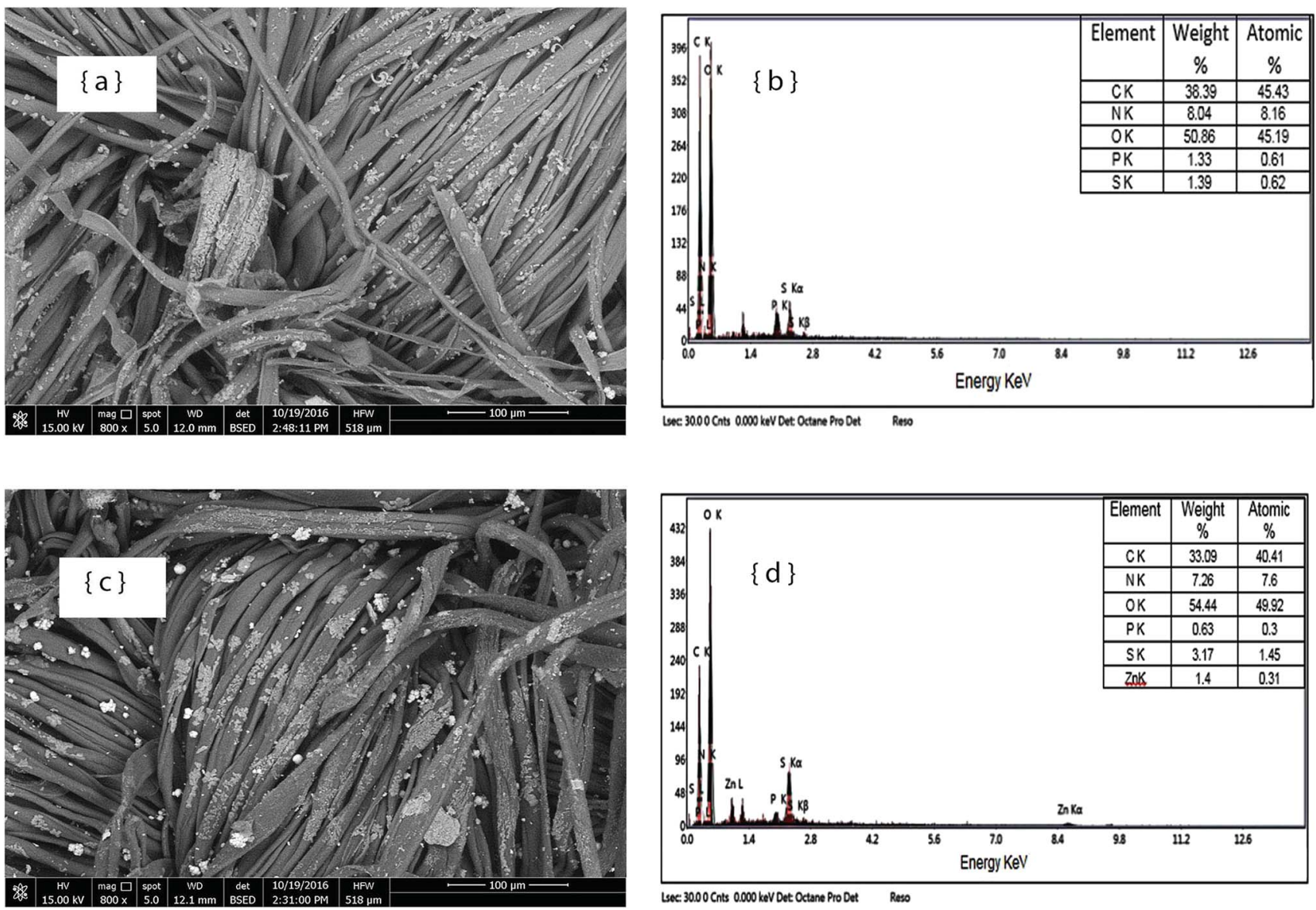

Fig. 5 SEM images and EDX spectra of cotton fabric finished with flame proofing agent (Flavon® CWF) (a and b); and finished with flame proofing agent in the presence of $\mathrm{ZnO}-\mathrm{NPs}$ ( $c$ and $d)$.

Table 1 Effect of individual inclusion of the nanometal oxides into the easy-care finishing formulation ${ }^{a}$

\begin{tabular}{|c|c|c|c|c|c|c|c|c|c|c|c|c|c|c|c|c|c|c|}
\hline \multirow{2}{*}{$\begin{array}{l}\text { Nanometal } \\
\text { oxide } \\
\left(25 \mathrm{~g} \mathrm{~L}^{-1}\right)\end{array}$} & \multicolumn{6}{|c|}{ Cotton } & \multicolumn{6}{|c|}{ Cotton/polyester (65/35) } & \multicolumn{6}{|c|}{ Cotton/polyester (50/50) } \\
\hline & $\begin{array}{l}\mathrm{N}^{b} \\
(\%)\end{array}$ & $\begin{array}{l}\mathrm{WRA}^{c} \\
(\mathrm{~W}+\mathrm{F})^{\circ}\end{array}$ & $\begin{array}{l}\mathrm{SR}^{d} \\
(\mu \mathrm{m})\end{array}$ & $\mathrm{UPF}^{e}$ & \multicolumn{2}{|c|}{$\mathrm{ZI}^{f}(\mathrm{~mm})$} & $\begin{array}{l}\mathrm{N}^{b} \\
(\%)\end{array}$ & $\begin{array}{l}\mathrm{WRA}^{c} \\
(\mathrm{~W}+\mathrm{F})^{\circ}\end{array}$ & $\begin{array}{l}\mathrm{SR}^{d} \\
(\mu \mathrm{m})\end{array}$ & $\mathrm{UPF}^{e}$ & \multicolumn{2}{|c|}{$\mathrm{ZI}^{f}(\mathrm{~mm})$} & $\begin{array}{l}\mathrm{N}^{b} \\
(\%)\end{array}$ & $\begin{array}{l}\mathrm{WRA}^{c} \\
(\mathrm{~W}+\mathrm{F})^{\circ}\end{array}$ & $\begin{array}{l}\mathrm{SR}^{d} \\
(\mu \mathrm{m})\end{array}$ & $\mathrm{UPF}^{e}$ & \multicolumn{2}{|c|}{$\mathrm{ZI}^{f}(\mathrm{~mm})$} \\
\hline None & 0.456 & 200 & 16.83 & 16 & 2.0 & 1.5 & 0.435 & 235 & 16.12 & 25 & 3.0 & 2.0 & 0.379 & 250 & 14.32 & 33 & 3.5 & 2.5 \\
\hline $\mathrm{ZrO}_{2}$ & 0.458 & 208 & 16.89 & 35 & 11.5 & 9.0 & 0.436 & 240 & 16.24 & 45 & 13.0 & 11.0 & 0.380 & 258 & 14.40 & 67 & 14.5 & 12.5 \\
\hline Untreated & - & 125 & 20.32 & 9 & - & - & - & 160 & 17.99 & 15 & - & - & - & 195 & 16.84 & 20 & - & - \\
\hline
\end{tabular}

${ }^{a}$ Finishing bath constituents: Arkofix® NEC $\left(50 \mathrm{~g} \mathrm{~L}^{-1}\right) ; \mathrm{MgCl}_{2} \cdot 6 \mathrm{H}_{2} \mathrm{O} /$ citric acid $\left(10 / 2 \mathrm{~g} \mathrm{~L}^{-1}\right)$; silicone softener $\left(30 \mathrm{~g} \mathrm{~L}^{-1}\right)$; nanometal oxide $\left(25 \mathrm{~g} \mathrm{~L}{ }^{-1}\right)$; nonionic wetting agent $\left(2 \mathrm{~g} \mathrm{~L}^{-1}\right)$; wet-pickup $(80 \%)$; drying at $100{ }^{\circ} \mathrm{C} / 3 \mathrm{~min}$; curing at $150{ }^{\circ} \mathrm{C} / 3 \mathrm{~min} .{ }^{b}$ Nitrogen content. ${ }^{c}$ Wrinkle recovery angle (warp + weft). ${ }^{d}$ Surface roughness. ${ }^{e}$ Ultraviolet protection factor. ${ }^{f}$ Zone of inhibition; G+ve: Gram-positive bacteria (S. aureus); G-ve: Gram negative bacteria (E. coli).

(a) Easy-care finish:

2S-Cell.OH $+\mathrm{ROH}_{2} \mathrm{CN} \sim \sim$ F.Agent $\sim \mathrm{NCH}_{2} \mathrm{OR} \underset{\Delta}{\stackrel{\mathrm{H}^{+}}{\longrightarrow}}$ S-Cell.O. $\mathrm{H}_{2} \mathrm{CN} \sim \sim$ F.Agent $\sim \mathrm{NCH}_{2} \mathrm{O}$.Cell. $\mathrm{S}+2 \mathrm{ROH}$ Ether-crosslinked substrate (I) (b) Easy care-finish:
nS-Cell. OH + $\mathrm{ROH}_{2} \mathrm{CN} \sim \sim$ F.Agent $\sim \mathrm{NCH}_{2} \mathrm{OR}+\mathrm{H}_{2} \mathrm{~N} \sim \sim \mathrm{NH} \sim \sim \mathrm{AFSi} \stackrel{\Delta}{\stackrel{\mathrm{H}^{+}}{\longrightarrow}}$

Easy care/softener-finished substrate (II) 
(c) Loading of MO-NPs onto the substrate:

$$
\text { S-Cell }{ }^{\circ} \mathrm{OH},(\mathrm{I}),(\mathrm{II})+\mathrm{MO}-\mathrm{NPs} \underset{\Delta}{\stackrel{\mathrm{H}^{+}}{\longrightarrow}} \mathrm{MO}-\mathrm{NPs}-\text { loaded/easy-care/softener finished substrates }
$$

The extent of loading of the nominated MO-NPs onto and/or within the finish/fabric matrix via physical adhesion and physical entrapment, as well as via chemical interaction with potential reactive sites such as $-\mathrm{OH}$ and $-\mathrm{COOH}$ terminal groups of the substrate, $\sim \sim \mathrm{NH}$ and $\sim \sim \mathrm{NH}_{2}$ groups of the reactive silicone softener within the finish/fabric matrix at acidic $\mathrm{pH}$ and at high temperature during the fixation step, significantly affects the imparted multifunctional properties.

\subsection{UV-protection finish}

The results in Table 2 clearly show that: (i) finishing of the untreated substrates with the reactant resin along with the organic UV-absorber, UV-Sun ${ }^{\circledR}$, results in a remarkable increase in \% N, WRA and UPF values, along with an improvement in the antibacterial functionality of the treated substrates; (ii) the enhancement in the imparted properties is governed by the type of substrate, as well as the extent of the loading of the UVabsorber onto the finish/fabric matrix as follows: the slight improvement in the antibacterial activity are attributed to the phenolic nature of the UV-absorber, as an oxalic acid dianilide derivative, and its ability to dissipate the UV-energy without radiation; ${ }^{5,35}$ (iv) the extent of the improvement in the fabric resiliency and functionality is governed by the type of substrate, as mentioned before, and follows the decreasing order: cotton/polyester $(50 / 50)>$ cotton/polyester $(65 / 35)>$ cotton $(100 \%)$, keeping other parameters constant.

The results in Table 2 also demonstrate that: (i) the incorporation of any of the nominated nanomaterials, $\mathrm{ZrO}, \mathrm{ZnO}$ or $\mathrm{TiO}_{2}-\mathrm{NPs}$, as a UV-blocking agent in the reactant resin/organic UV-absorber finishing formulation brings about a slight decrease in $\% \mathrm{~N}$, a reasonable improvement in fabric resiliency, excellent UV-protection properties (UPF: $50^{+}$), and a remarkable improvement in antibacterial functionality against both the G+ve and G-ve pathogens, irrespective of the used substrate; (ii) the remarkable improvement in the UV-protection functionality reflects the outstanding ability of the loaded

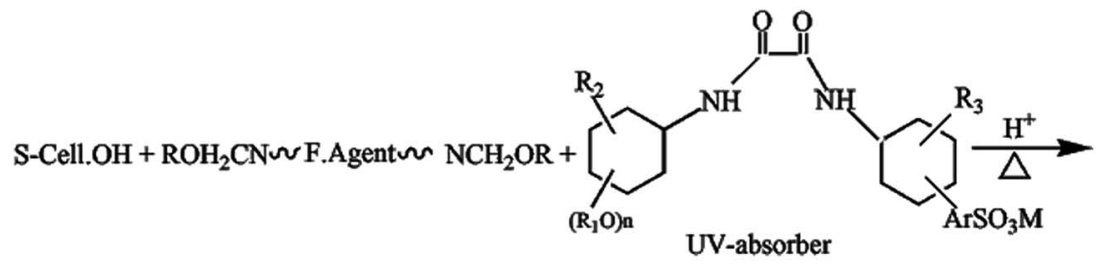

UV-absorber-loaded substrate

via chemical interactions among $\sim$ Cell.OH groups of the substrate, $\sim \sim \mathrm{NCH}_{2} \mathrm{OR}$ groups of the reactant resin and $\sim \sim \mathrm{NH} \sim \sim$ groups of the UV-absorber under the curing conditions, as well as via hydrogen bonding; (iii) the significant increase in the UVprotection functionality of the UV-Sun ${ }^{\circledR}$-loaded substrates and nanomaterials to scatter/refract and shield the harmful UV-B rays, thereby upgrading the protection capacity of the multifinished substrates; (iii) the significant increase in the imparted antibacterial efficacy of the nanometal oxide-loaded substrates is attributed to their photocatalytic activity and ability to

Table 2 Effect of individual inclusion of the nanometal oxides into the anti-UV finishing formulation ${ }^{a}$

\begin{tabular}{|c|c|c|c|c|c|c|c|c|c|c|c|c|c|c|c|}
\hline \multirow{3}{*}{$\begin{array}{l}\text { Nanometal } \\
\text { oxide } \\
\left(25 \mathrm{~g} \mathrm{~L}^{-1}\right)\end{array}$} & \multicolumn{5}{|l|}{ Cotton } & \multicolumn{5}{|c|}{ Cotton/polyester $(65 / 35)$} & \multicolumn{5}{|c|}{ Cotton/polyester $(50 / 50)$} \\
\hline & \multirow[b]{2}{*}{$\mathrm{N}^{b}(\%)$} & \multirow{2}{*}{$\begin{array}{l}\mathrm{WRA}^{c} \\
(\mathrm{~W}+\mathrm{F})^{\circ}\end{array}$} & \multirow[b]{2}{*}{$\mathrm{UPF}^{d}$} & \multicolumn{2}{|c|}{$\mathrm{ZI}^{e}(\mathrm{~mm})$} & \multirow[b]{2}{*}{$\mathrm{N}^{b}(\%)$} & \multirow{2}{*}{$\begin{array}{l}\mathrm{WRA}^{c} \\
(\mathrm{~W}+\mathrm{F})^{\circ}\end{array}$} & \multirow[b]{2}{*}{$\mathrm{UPF}^{d}$} & \multicolumn{2}{|c|}{$\mathrm{ZI}^{e}(\mathrm{~mm})$} & \multirow[b]{2}{*}{$\mathrm{N}^{b}(\%)$} & \multirow{2}{*}{$\begin{array}{l}\mathrm{WRA}^{c} \\
(\mathrm{~W}+\mathrm{F})^{\circ}\end{array}$} & \multirow[b]{2}{*}{$\mathrm{UPF}^{d}$} & \multicolumn{2}{|c|}{$\mathrm{ZI}^{e}(\mathrm{~mm})$} \\
\hline & & & & G+ve & $\mathrm{G}-\mathrm{ve}$ & & & & G+ve & $\mathrm{G}$-ve & & & & $\mathrm{G}+\mathrm{ve}$ & $\mathrm{G}-\mathrm{ve}$ \\
\hline None & 0.413 & 185 & 44 & 2.5 & 2.0 & 0.392 & 204 & 58 & 3.0 & 2.5 & 0.351 & 232 & 70 & 3.5 & 3.0 \\
\hline $\mathrm{ZrO}$ & 0.386 & 189 & 52 & 13 & 11 & 0.383 & 210 & 69 & 15 & 13 & 0.338 & 240 & 85 & 16 & 15 \\
\hline $\mathrm{ZnO}$ & 0.362 & 205 & 68 & 18 & 16 & 0.350 & 219 & 89 & 19 & 17.5 & 0.310 & 254 & 114 & 21 & 20 \\
\hline $\mathrm{TiO}_{2}$ & 0.374 & 210 & 96 & 15 & 14 & 0.368 & 232 & 114 & 17 & 15 & 0.330 & 265 & 130 & 18 & 17 \\
\hline Untreated & - & 125 & 9 & - & - & - & 160 & 15 & - & - & - & 195 & 20 & - & - \\
\hline
\end{tabular}

${ }^{a}$ Finishing bath constituents: Arkofix® NEC $\left(50 \mathrm{~g} \mathrm{~L}^{-1}\right) ; \mathrm{MgCl}_{2} \cdot 6 \mathrm{H}_{2} \mathrm{O} /$ citric acid $\left(10 / 2 \mathrm{~g} \mathrm{~L}^{-1}\right)$; UV-Sun® $\left(25 \mathrm{~g} \mathrm{~L}^{-1}\right)$; nanometal oxide $\left(25 \mathrm{~g} \mathrm{~L}{ }^{-1}\right)$; nonionic wetting agent $\left(2 \mathrm{~g} \mathrm{~L}^{-1}\right)$; wet-pickup (80\%); drying at $100{ }^{\circ} \mathrm{C} / 3 \mathrm{~min}$; curing at $150{ }^{\circ} \mathrm{C} / 3 \mathrm{~min} .{ }^{b}$ Nitrogen content. ${ }^{c}$ Wrinkle recovery angle (warp + weft). ${ }^{d}$ Ultraviolet protection factor. ${ }^{e}$ Zone of inhibition; G+ve: Gram-positive bacteria (S. aureus); G-ve: Gram negative bacteria (E. coli). 
generate extremely reactive oxygen species (ROS) in the presence of light and water, which can attack, damage and finally destroy the harmful bacteria cells as follows: ${ }^{35-37}$

$$
\begin{gathered}
\text { MO-NPs }+h \nu \rightarrow \text { MO-NPs }\left(\mathrm{e}_{\mathrm{cb}}^{-}+\mathrm{h}_{\mathrm{vb}}{ }^{+}\right) \\
\mathrm{e}^{-}+\mathrm{O}_{2} \rightarrow{ }^{\cdot} \mathrm{O}_{2}{ }^{-} \\
\mathrm{O}_{2}^{-}+\mathrm{H}_{2} \mathrm{O}\left(\mathrm{H}^{+\cdot-} \mathrm{OH}\right) \rightarrow \mathrm{HO}_{2}{ }^{-}+\mathrm{OH} \\
2 \mathrm{HO}_{2}^{\cdot} \rightarrow \mathrm{O}_{2}+\mathrm{H}_{2} \mathrm{O}_{2} \\
\mathrm{H}_{2} \mathrm{O}_{2}+{ }^{\cdot} \mathrm{O}_{2}^{-} \rightarrow \cdot \mathrm{OH}+\mathrm{OH}+\mathrm{O}_{2} \\
\mathrm{~h}^{+}+\mathrm{H}_{2} \mathrm{O}\left(\mathrm{H}^{+\cdot} \mathrm{OH}\right) \rightarrow \mathrm{H}^{+}+{ }^{\cdot} \mathrm{OH}
\end{gathered}
$$

Harmful bacteria + ROS $\rightarrow$ destroyed pathogenic bacteria cells

where $h \nu$ represents UV-light, $\mathrm{e}^{-}$is a highly reactive electron, $\mathrm{h}^{+}$ represents a hole, $\mathrm{cb}$ is the conduction band, $\mathrm{vb}$ is the valence band, ROS represents reactive oxygen species ( ${ }^{\circ} \mathrm{OH},{ }^{\circ} \mathrm{O}_{2}{ }^{-}, \mathrm{H}_{2} \mathrm{O}_{2}$ ) and MO-NPs are the nanometal oxides.

On the other hand, the extent of the improvement in the imparted functionalities is governed by: (i) the type, particle size, amount, location, photocatalytic activity and shielding capacity of the incorporated MO-NPs; (ii) the synergistic effect of both the organic UV-absorber, UV-Sun ${ }^{\circledR}$, and the MO-NP UVblocker; (iii) the extent of the interactions among the nominated active ingredients and the cellulose-containing fabrics under the given thermofixation conditions.

\subsection{Water/oil repellent finish}

Table 3 shows that the incorporation of the dispersed fluoropolymer, Oleophobol ${ }^{\circledR} \mathrm{CO}$, together with the reactant resin and the mixed catalyst under the given thermofixation conditions results in a significant improvement in \% N, UPF, WRR and ORR values, along with a reasonable increase in the fabric resiliency and antibacterial activity of the treated substrates, compared with the untreated ones. The enhancement in the aforementioned properties reflects the positive role of the used finishing agents in enhancing the extent of crosslinking and fixation of the fluorocarbon polymer onto the nominated fabric surfaces, thereby changing the surface morphology, decreasing the surface free energy and creating water/oil repellent fabric surfaces. ${ }^{38,39}$

On the other hand, incorporation of any of the nominated nanometal oxides into the conventional water/oil repellent finishing formulation results in a slight decrease in $\% \mathrm{~N}$, along with a remarkable improvement in easy-care, UV-protection, water/oil repellency and antibacterial functionalities, regardless of the treated substrate and type of MO-NPs. The enhancement in the imparted functional properties of the treated substrates reflects the positive role of the utilized nanometal oxides in: (i) enhancing the extent of fixation, as well as the orientation of the fluorine-containing polymer onto the fabric surfaces, thereby improving the effectiveness and film forming properties; (ii) changing the surface topography and

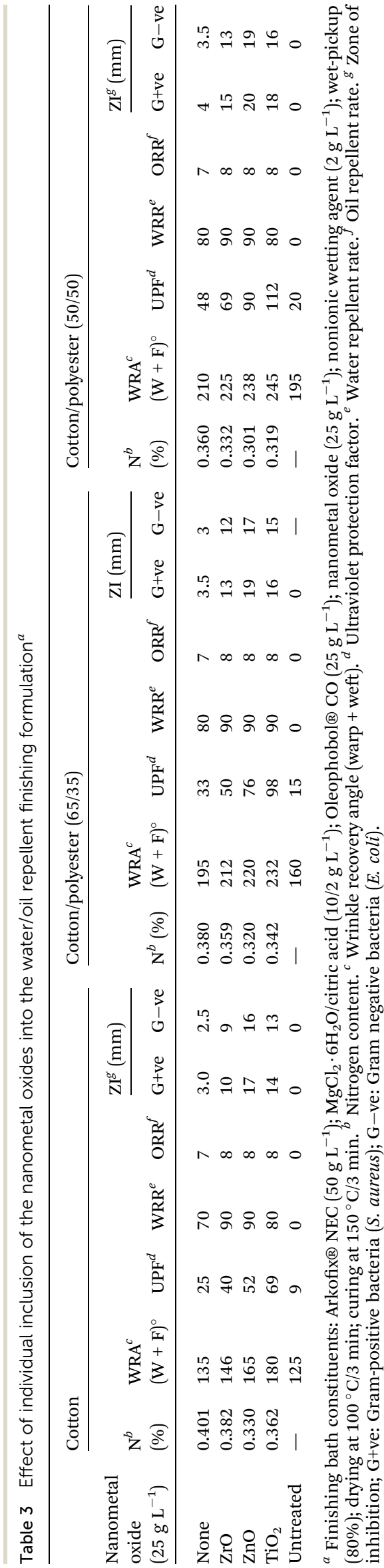


Table 4 Effect of individual inclusion of the nanometal oxides into the antibacterial finishing formulation ${ }^{a}$

\begin{tabular}{|c|c|c|c|c|c|c|c|c|c|c|c|c|c|c|c|}
\hline \multirow{3}{*}{$\begin{array}{l}\text { Nanometal } \\
\text { oxide } \\
\left(25 \mathrm{~g} \mathrm{~L}^{-1}\right)\end{array}$} & \multicolumn{5}{|l|}{ Cotton } & \multicolumn{5}{|c|}{ Cotton/polyester (65/35) } & \multicolumn{5}{|c|}{ Cotton/polyester (50/50) } \\
\hline & \multirow[b]{2}{*}{$\mathrm{N}^{b}(\%)$} & \multirow{2}{*}{$\begin{array}{l}\mathrm{WRA}^{c} \\
(\mathrm{~W}+\mathrm{F})^{\circ}\end{array}$} & \multirow[b]{2}{*}{$\mathrm{UPF}^{d}$} & \multicolumn{2}{|c|}{$\mathrm{ZI}^{e}(\mathrm{~mm})$} & \multirow[b]{2}{*}{$\mathrm{N}^{b}(\%)$} & \multirow{2}{*}{$\begin{array}{l}\mathrm{WRA}^{c} \\
(\mathrm{~W}+\mathrm{F})^{\circ}\end{array}$} & \multirow[b]{2}{*}{$\mathrm{UPF}^{d}$} & \multicolumn{2}{|c|}{$\mathrm{ZI}^{e}(\mathrm{~mm})$} & \multirow[b]{2}{*}{$\mathrm{N}^{b}(\%)$} & \multirow{2}{*}{$\begin{array}{l}\mathrm{WRA}^{c} \\
(\mathrm{~W}+\mathrm{F})^{\circ}\end{array}$} & \multirow[b]{2}{*}{$\mathrm{UPF}^{d}$} & \multicolumn{2}{|c|}{$\mathrm{ZI}^{e}(\mathrm{~mm})$} \\
\hline & & & & G+ve & $\mathrm{G}-\mathrm{ve}$ & & & & G+ve & $\mathrm{G}-\mathrm{ve}$ & & & & G+ve & G-ve \\
\hline None & 0.416 & 136 & 25 & 15.0 & 13.0 & 0.401 & 185 & 40 & 17.0 & 16.0 & 0.385 & 205 & 52 & 18.5 & 17.0 \\
\hline $\mathrm{ZrO}$ & 0.394 & 145 & 39 & 17.0 & 16.0 & 0.371 & 203 & 50 & 19.5 & 18.0 & 0.358 & 220 & 69 & 22.0 & 21.0 \\
\hline $\mathrm{ZnO}$ & 0.346 & 158 & 53 & 21.0 & 19.0 & 0.330 & 215 & 70 & 23.0 & 22.0 & 0.313 & 230 & 97 & 24.5 & 23.0 \\
\hline $\mathrm{TiO}_{2}$ & 0.365 & 170 & 69 & 18.5 & 17.0 & 0.348 & 226 & 85 & 21.0 & 19.5 & 0.336 & 238 & 112 & 23.0 & 22.0 \\
\hline Untreated & - & 125 & 9 & 0.0 & 0.0 & - & 160 & 15 & 0.0 & 0.0 & - & 192 & 20 & 0.0 & 0.0 \\
\hline
\end{tabular}

${ }^{a}$ Finishing bath constituents: Arkofix® NEC $\left(50 \mathrm{~g} \mathrm{~L}^{-1}\right) ; \mathrm{MgCl}_{2} \cdot 6 \mathrm{H}_{2} \mathrm{O} /$ citric acid $\left(10 / 2 \mathrm{~g} \mathrm{~L}^{-1}\right)$; HEIQ® Pure TF (30 g L $\left.{ }^{-1}\right)$; nanometal oxide (25 g L $\left.{ }^{-1}\right)$; nonionic wetting agent $\left(2 \mathrm{~g} \mathrm{~L}^{-1}\right)$. Wet-pickup (80\%); drying at $100{ }^{\circ} \mathrm{C} / 3 \mathrm{~min}$; curing at $150{ }^{\circ} \mathrm{C} / 3 \mathrm{~min} .{ }^{b}$ Nitrogen content. ${ }^{c}$ Wrinkle recovery angle (warp + weft). ${ }^{d}$ Ultraviolet protection factor. ${ }^{e}$ Zone of inhibition; G+ve: Gram-positive bacteria (S. aureus); G-ve: Gram negative bacteria (E. coli).

increasing the surface roughness, thereby leading to better hydrophobic effects than when the hydrophobic agent is applied alone, keeping other additives fixed. Furthermore, the presence of the MO-NPs fixed into the finish/fabric matrix, with their UV-shielding and photocatalytic properties, confers additional and better multifunctional properties to the treated cellulose-containing fabrics than those treated in the absence of MO-NPs. ${ }^{40,41}$ Additionally, the extent of the improvement in the multifunctional properties of the treated substrates is governed by fabric type, type of MO-NPs, extent of interaction and the fixation of active ingredients on the fabric surface, as well as the change in the surface morphology and surface tension of the nominated substrate in the absence and presence of the nanometal oxides.

\subsection{Antibacterial finish}

The results in Table 4 reveal that treating the nominated substrates with HEIQ ${ }^{\circledR}$ Pure TF, a cationic antimicrobial agent containing silver, along with the crosslinking agent and mixed catalyst, results in an improvement in \% N, WRA and UPF values, along with a remarkable increase in the antibacterial activity of the treated substrates. The variation in the imparted functionality is determined by the type of substrate. The fixation of the antimicrobial agent onto/within the finish/fabric matrix changes the surface and chemical properties of the treated substrates, thereby enhancing the nitrogen content, fabric resiliency and UV-shielding ability. On the other hand, the remarkable improvement in the antibacterial functionality is attributed to the interaction of the positively charged cationic sites of the antimicrobial agent with the negatively charged cell walls of the pathogens, which in turn causes the interruption of cell membrane functions and protein activity, as well as the inability to multiply. ${ }^{25,42}$ Further, $\mathrm{Ag}$ in the finish/fabric matrix can participate in: (i) hindering or deactivating the physiological functions of the bacteria; (ii) interacting with thiol groups and/or binding of $\mathrm{Ag}^{+}$to the DNA; (iii) accelerating the formation of reactive oxygen species, highly toxic to cells, and consequently destroying the bacterial cells, as follows: ${ }^{2,43,44}$

$$
4 \mathrm{Ag}+\mathrm{O}_{2}+\mathrm{H}_{2} \mathrm{O} \rightarrow 4 \mathrm{Ag}^{+}+4 \mathrm{OH}^{-}
$$

$$
\mathrm{H}_{2} \mathrm{O}+1 / 2 \mathrm{O}_{2} \stackrel{\mathrm{Ag}^{+} \text {and } / \text { or Ag NPs }}{\longrightarrow} \mathrm{H}_{2} \mathrm{O}_{2} \rightarrow \mathrm{ROS}+\mathrm{H}_{2} \mathrm{O}
$$

The results in Table 4 demonstrate also that inclusion of any of the nominated MO-NPs into the finishing formulation, along with other active ingredients, leads to much better functional properties, i.e. easy-care, UV-protection and antibacterial functionality, along with lower $\% \mathrm{~N}$ values, than those of the samples finished in the absence of the nanometal oxides, i.e. the control samples.

The noticeable improvement in the imparted functionalities of the treated substrates is a direct consequence of binding/ embedding MO-NPs onto/into the finish/fabric matrix, which in turn enhances: (i) the catalytic effect of the used mixed catalyst; (ii) the extent of the interactions among the treated substrate active sites and the crosslinking and antimicrobial finishing agents used; (iii) the UV-blocking capability and antibacterial functionality, as discussed earlier. Additionally, the improvement in the evaluated functional properties reflects the synergetic effect of adding the nominated nanomaterials to the conventional finishing agents in one bath.

The obtained results also signify that the enhancement in the functional properties is directly affected by the characteristics of the substrate, such as its chemical nature, surface morphology, adsorption capacity, active groups and available binding sites. This enhancement is also related to the properties of the MO-NPs, such as their chemical structure, particle size, specific surface used, photocatalytic activity, and synergetic effect. Other factors include the mode of interaction, extent of fixation and loading of the active ingredients onto/ within the finish/fabric matrix, and the degree of agglomeration of the NPs, which in turn controls the release of MO-NPs from the coated fabric surface.

The enhancement in the imparted functionalities using the nominated MO-NPs can be ranked in descending order as follows:

(i) Regarding easy-care and UV-blocking functions: $\mathrm{TiO}_{2}-\mathrm{NPs}$ $>$ ZnO-NPs $>$ ZrO-NPs $>$ control $\gg$ untreated.

(ii) Regarding antibacterial function: $\mathrm{ZnO}-\mathrm{NPs}>\mathrm{TiO}_{2}-\mathrm{NPs}>$ ZrO-NPs $>$ control $\gg$ untreated, keeping other parameters constant. 


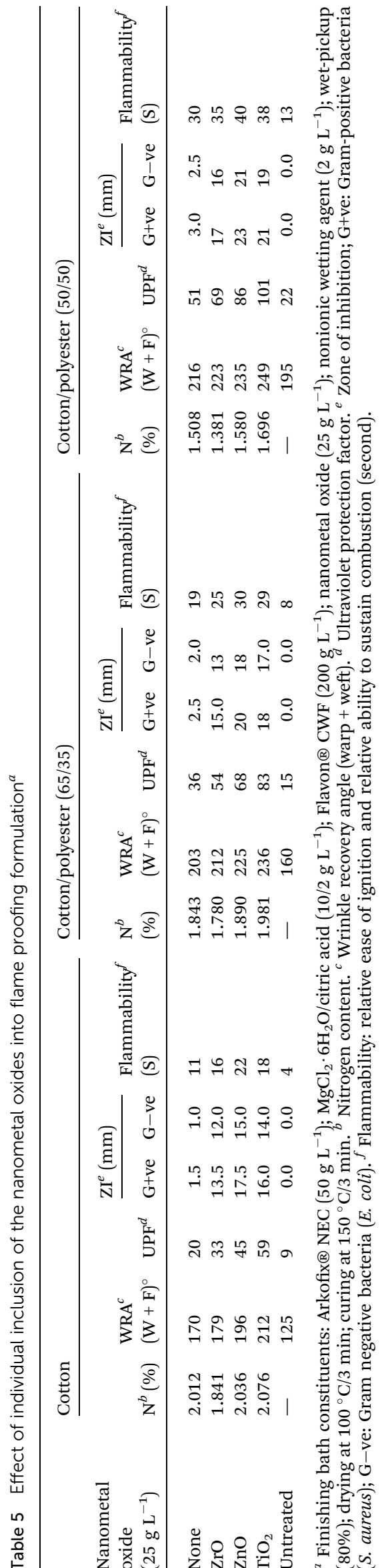

\subsection{Flame retardant finish}

The impacts of the individual inclusion of the nominated nanometal oxides into the conventional flame retardant finish formulation are summarized in Table 5 . It is clear that conventional finishing of untreated substrates with Flovan ${ }^{\circledR}$ CWF as a flame retardant agent, along with Arkofix® NEC as a crosslinking agent, under the given conditions results in a significant increase in the nitrogen content, fabric resiliency, UV-shielding ability, flame retardancy functional properties and antibacterial activity of the treated substrates. The remarkable improvement in the burning performance, expressed as burning time in seconds, can be discussed in terms of the ability of the flame retardant components used, nitrogen/ phosphate/sulfate compounds, and the crosslinker to change the pyroltic pathways of thermal decomposition of the nominated substrates, or the ability to form a protective coating or barrier on the surface of the decomposing substrate..$^{45,46}$

Table 5 also shows that the addition of any of the nominated MO-NPs in the conventional flame-retardant finishing formulations is accompanied by a slight variation in $\% \mathrm{~N}$, a reasonable improvement in WRA, and significant increases in UPF, antibacterial activity and burning time, regardless of the treated substrate. The enhancements in the imparted functionalities, gained through modifying the finishing formulation, reflect the positive impacts of the added MO-NPs on the surface morphology, location and distribution of crosslinks, creation of antibacterial active sites on the finish/ fabric matrix and thermal stability and fire-retardant functionality of the treated substrates, thereby improving UVprotection, easy-care, antibacterial activity and increasing the flammability time, respectively. ${ }^{47}$ The enhancement in the flame retardant attributes of the treated substrates is governed by the type of immobilized MO-NPs, and their thermal stability, synergetic effects, ability to act as a barrier to heat and mass transfer, capability to change the degradation pathway of the textile polymer and ability to hinder the mobility of textile polymer chains and/or to absorb the generated active species ${ }^{48}$ keeping other parameters fixed. The degree of fixation of both the phosphorous sulfur and nitrogen components to the finish/fabric matrix cannot be rolled out. Moreover, the results in Table 5 demonstrate that the enhancement in flame-retardant functionality as a function of the added MO-NPs can be ranked as: $\mathrm{ZnO}-\mathrm{NPs}>\mathrm{TiO}_{2}-\mathrm{NPs}>$ ZrO-NPs $>$ control $\gg$ untreated, keeping the type of substrate fixed. Additionally, the change in the evaluated functional property values upon using the nominated MO-NPs is governed by their type, photocatalytic activity, thermal stability and compatibility with other ingredients in the conventional finishing formulation, as mentioned before.

\section{Conclusion}

A new approach for improving and/or imparting new functional properties to cotton-containing fabrics in one step was investigated by including $\mathrm{ZrO}-\mathrm{NPs}, \mathrm{ZnO}-\mathrm{NPs}$ or $\mathrm{TiO}_{2}-\mathrm{NPs}$ into the traditional finishing formulations. 
The obtained results demonstrate that the incorporation of the nominated MO-NPs into an easy-care/softener finishing formulation is accompanied by an enhancement in fabric resiliency and surface softness, along with a noticeable improvement in UV-protection and antibacterial functionalities, regardless of the type of MO-NPs or treated substrates. Inclusion of the nominated MO-NPs into UV-protection finish formulation brings about a remarkable improvement in the UVprotection functionality, along with a significant improvement in the antibacterial efficacy and a reasonable increase in fabric resiliency, irrespective of the used MO-NPs and the finished substrate. We have also shown that the addition of the nominated MO-NPs into a water/oil repellent finishing formulation results in significant improvements in UPF, ERR and ORR values, along with a reasonable improvement in fabric resiliency, and the extent of improvement is determined by the type of MO-NPs and the kind of substrate. Coating the substrates with the antibacterial finish in the presence of the nanometal oxides also results in a remarkable improvement in the antibacterial activity according to the following order: ZnO-NPs > $\mathrm{TiO}_{2}-\mathrm{NPs}>\mathrm{ZrO}-\mathrm{NPs}>$ control $>>$ untreated, along with an enhancement in the UPF values as follows: $\mathrm{TiO}_{2}-\mathrm{NPs}>\mathrm{ZnO}-$ NPs $>$ ZrO-NPs $>$ control $>>$ untreated, keeping the other parameters constant. Furthermore, the addition of any of the nominated MO-NPs to the conventional flame retardant finishing formulation results in a significant increase in burning time, UPF and antibacterial activity along with a reasonable increase in fabric resiliency. The enhancement of the flame retardant properties as a function of the type of MO-NPs can be ranked as: $\mathrm{ZnO}-\mathrm{NPs}>\mathrm{TiO}_{2}-\mathrm{NPs}>\mathrm{ZrO}-\mathrm{NPs}>$ control >> untreated. Finally, this very simple and easily scaled-up single step process can be applied to achieve multifunctional textile products with outstanding performance and protective properties.

\section{References}

1 M. Mahbubul Bashar and M. A. Khan, J. Polym. Environ., 2013, 21, 181-190.

2 N. A. Ibrahim, B. M. Eid and H. El-Batal, Carbohydr. Polym., 2012, 87, 744-751.

3 T. Harifi and M. Montazer, Carbohydr. Polym., 2012, 88, 1125-1140.

4 I. Holme, Color. Technol., 2007, 123, 59-73.

5 W. D. Schindler and P. J. Hauser, Chemical finishing of textile, Woodhead publishing Ltd, 2004.

6 M. L. Gulrajani and D. Gupta, Indian J. Fibre Text. Res., 2011, 36, 388-397.

7 N. A. Ibrahim, B. M. Eid, M. A. Youssef, H. M. Ibrahim, H. A. Ameen and A. M. Salah, Carbohydr. Polym., 2013, 97, 783-793.

8 M. M. G. Fouda and H. M. Fahmy, Carbohydr. Polym., 2011, 86, 625-629.

9 A. Hebeish, F. A. Abdel-Mohdy, M. M. G. Fouda, Z. Elsaid, S. Essam, G. H. Tammam and E. A. Drees, Carbohydr. Polym., 2011, 86, 1684-1691.
10 M. Hashem, M. H. Elshakankery, S. M. A. El-Aziz, M. M. G. Fouda and H. M. Fahmy, Carbohydr. Polym., 2011, 86, 1692-1698.

11 M. M. G. Fouda, A. El Shafei, S. Sharaf and A. Hebeish, Carbohydr. Polym., 2009, 77, 651-655.

12 N. A. Ibrahim, B. M. Eid, E. Abd El-Aziz and T. M. Abou Elmaaty, Carbohydr. Polym., 2013, 97, 537-545.

13 N. A. Ibrahim, W. M. El-Zairy, M. R. El-Zairy, B. M. Eid and H. A. Ghazal, Carbohydr. Polym., 2011, 83, 1068-1074.

14 Y. Dong, Z. Bai, L. Zhang, R. Liu and T. Zhu, J. Appl. Polym. Sci., 2006, 99, 286-291.

15 A. I. Vogel, Elementary Practical Inorganic Chemistry, Longman, London, 2nd edn, 1975.

16 A. C. RR61 and American Association of Textile Chemists and Colorists, USA, 1995, vol. AATCC-66:1995.

17 J. I. S. Committee and Japanese Standards Association, Japan, 1994, vol. JIS B0601-'94.

18 A. C. RA31 and American Association of Textile Chemists and Colorists, USA, 1988, vol. AATCC147:1988.

19 S. P. C. J. T. C. TX/21 and Council of Standards Australia \& Council of Standards New Zealand Australian/New Zealand, Australian/New Zealand, 1996, vol. AS/NZS 4399:1996.

20 A. C. RA63 and American Association of Textile Chemists and Colorists, USA, 2005, vol. AATCC22:2005.

21 A. C. RA56 and American Association of Textile Chemists and Colorists, USA, 2013, vol. AATCC TM118:2013.

22 U. S. C. P. S. Commission, USA, 2008, vol. 16, CFR Part 1610.

23 Y.-L. Lam, C.-W. Kan and C.-W. M. Yuen, Text. Prog., 2012, 44, 175-249.

24 N. A. Ibrahim, T. M. Abou Elmaaty, B. M. Eid and E. Abd ElAziz, Carbohydr. Polym., 2013, 95, 379-388.

25 M. Radetić, J. Photochem. Photobiol., C, 2013, 16, 62-76.

26 L. Rizzello, R. Cingolani and P. P. Pompa, Nanomedicine, 2013, 8, 807-821.

27 N. A. Ibrahim, B. M. Eid, M. M. Hashem, R. Refai and M. ElHossamy, J. Ind. Text., 2010, 39, 233-265.

28 N. A. Ibrahim, D. F. Ibrahim, M. Eid Basma, M. R. El-Zairy and E. M. Emam, J. Text. Inst., 2017, 1-11, DOI: 10.1080/ 00405000.2017 .1281716 .

29 M. Hashem, N. A. Ibrahim, A. El-Shafei, R. Refaie and P. Hauser, Carbohydr. Polym., 2009, 78, 690-703.

30 I. Cerkez, H. B. Kocer, S. D. Worley, R. M. Broughton and T. S. Huang, J. Appl. Polym. Sci., 2012, 124, 4230-4238.

31 Y. Gao and R. Cranston, Text. Res. J., 2008, 78, 60-72.

32 M. A. Hossain and M. Rahman, Journal of Textile Science and Technology, 2015, 1, 93-100.

33 T. Tsuzuki and X. Wang, Res. J. Text. Apparel, 2010, 14, 9-20. 34 M. D. Teli, in Functional finishes for textiles: improving comfort, performance and protection, ed. P. Roshan, Cambridge Woodhead Publishing Amsterdam Elsevier, 2015, pp. 133-135.

35 Y. K. Kim, in Functional finishes for textiles: improving comfort, performance and protection, ed. P. Roshan, Cambridge Woodhead Publishing Amsterdam Elsevier, UK, 2015, pp. 473-456.

36 N. A. Ibrahim, R. Refaie and A. F. Ahmed, J. Ind. Text., 2010, 40, 65-83. 
37 A. P. S. Sawhney, B. Condon, K. V. Singh, S. S. Pang, G. Li and D. Hui, Text. Res. J., 2008, 78, 731-739.

38 U. Y. Yıldız, Ç. Aslan, M. E. Üreyen, A. S. Koparal and A. Doğan, Properties of Textile Fabrics Treated with Antibacterial and Repellent Finishes, AUTEX 2012, Zadar, Croatia, 13-15 June 2012.

39 N. A. Ibrahim, A. Amr, B. M. Eid and Z. M. El-Sayed, Carbohydr. Polym., 2010, 82, 1198-1204.

40 B. Mahltig, in Functional finishes for textiles: Improving comfort, performance and protection, ed. P. Paul, Elsevier, UK, 2015, ch. 15, pp. 405-407.

41 S. Park, J. Kim and C. H. Park, J. Eng. Fiber Fabr., 2015, 10, 1-17. 42 N. A. Ibrahim, in Nanotechnology in Diagnosis, Treatment and Prophylaxis of Infectious Diseases, ed. M. Rai and K. Kon, Elsevier Publisher, UK, 2015, ch. 12, pp. 191-216.
43 B. Simončič and D. Klemenčič, Text. Res. J., 2016, 86, 210223.

44 N. A. Ibrahim, D. F. Ibrahim, W. M. Elzairy, B. M. Eid and T. M. Tawfk, Advanced Research in Textile Engineering, 2016, 1, 1007.

45 S. Gaan, G. Sun, K. Hutches and M. H. Engelhard, Polym. Degrad. Stab., 2008, 93, 99-108.

46 A. R. Horrocks, Rev. Prog. Color. Relat. Top., 1986, 16, 62-101. 47 N. R. Dhineshbabu, P. Manivasakan, R. Yuvakkumar, P. Prabu and V. Rajendran, J. Nanosci. Nanotechnol., 2013, 13, 4017-4024.

48 M. Norouzi, Y. Zare and P. Kiany, Polym. Rev., 2015, 55, 531560. 